\title{
Impacts of rearing techniques on growth, survival and bacterial microbiota of carpet shell clam (Ruditapes decussatus) larvae
}

\author{
Amel Medhioub ${ }^{1} \cdot$ Badreddine Mechri $^{1,2} \cdot$ Sondes Bchir $^{1} \cdot$ \\ Younes Limeyem $^{1} \cdot$ Wissem Slimani $^{1} \cdot$ Mahjoub Aouni ${ }^{2}$. \\ Mohamed Nejib Medhioub ${ }^{1}$
}

Received: 11 March 2016/ Accepted: 18 August 2016/Published online: 27 August 2016

(C) The Author(s) 2016. This article is published with open access at Springerlink.com

\begin{abstract}
In this study, we investigate the impacts of two water treatment regimes, the closed aquaculture system (CAS) and flow-through system (FTS), on the carpet shell clam (Ruditapes decussatus) larval microbiota, growth and survival. A bacteriological barrier (B) was created among breeder stage treated by florfenicol (FF, $8 \mathrm{mg} \mathrm{L}^{-1} \mathrm{day}^{-1}$ per 5 days). After spawning, larvae were maintained in five different rearing techniques: CAS; FTS; B + CAS; B + FTS and B + CAS + FF $\left(8 \mathrm{mg} \mathrm{L}^{-1}\right.$ day $^{-1}$ per 3 days $)$. Significant decrease was observed in both total bacterial count and presumptive Vibrio count (PVC) in FF-treated breeders. Besides, larvae reared in B + FTS showed significantly lower PVC than larvae maintained in other rearing techniques. It was also determined that growth and survival of larvae reared in B + CAS + FF and B + FTS were significantly better than those reared in other systems. One hundred and twelve Vibrio strains, isolated from breeders, eggs and larvae, were subjected to some bacteriological tests (API 20E strips, vibriostatic agent $\mathrm{O} / 129$, growth at different temperatures and salinity). Vibrio alginolyticus was the predominant isolated species (36.61\%), followed by V. fluvialis (25\%), V. vunificus $(17.86 \%)$, V. cholera $(13.39 \%)$ and V. paraheamolyticus $(7.14 \%)$. These results may contribute to the understanding of the effect of rearing techniques on the bacterial load, survival and growth of early life stages of $R$. decussatus larvae.
\end{abstract}

Keywords Ruditapes decussatus · Larval rearing · Flow-through system · Closed aquaculture system $\cdot$ Vibrionaceae

Amel Medhioub

amel.medhioub@instm.rnrt.tn

1 Laboratoire d'Aquaculture - Institut National des Sciences et Technologies de la Mer, Route de Khniss, B.P. 59, 5000 Monastir, Tunisia

2 Laboratoire des Maladies Transmissibles et Substances Biologiquement Actives, Faculté de Pharmacie, Université de Monastir, rue Avicenne, 5000 Monastir, Tunisia 


\section{Introduction}

The carpet shell clam, Ruditapes decussatus (Linnaeus 1758), is the most abundant and commercially important species of Veneridae in different North African estuaries and lagoons. In Tunisia, it is found predominantly in the Gulf of Gabes (Medhioub 1983) and its collecting represents a traditional activity that has a significant socioeconomic impact in terms of both income and employment. The development of this economic sector involves not only the rational management of beds but also the breeding of this species, which requires mass production of juveniles. To this aim, several basic and applied research programs have been conducted to develop new techniques for improvement in R. decussatus larval and post-larval reared in the experimental bivalve hatchery of the National Institute of Marine Sciences and Technology.

In general, $R$. decussatus larvae are produced in closed aquaculture systems (CASs), which represent the most common rearing method used in bivalve hatcheries (Castagna et al. 1996; Robert and Gérard 1999; Helm and Bourne 2004; Rico-Villa et al. 2006). However, there are some drawbacks, such as microbial contamination risk and disease transmission. In fact, larval culture tanks water is completely exchanged at least three times per week, allowing microbes to increase their biomass in the rearing water (Andersen et al. 2000; Torkildsen and Magnesen 2004). Despite the use of antibacterial agents as prophylactic therapy, we have been confronted with recurrent epizootic disease outbreaks in larval and early post-larval stages, causing high mortality (Mechri et al. 2015).

Nowadays, large varieties of water circulation systems are used in bivalve hatcheries, such as the flow-through systems (FTSs) and the recirculation aquaculture systems (RASs). The FTS is based on regular water exchange in order to reduce bacteria as well as toxic substances, which accumulate in the rearing water (New and Valenti 2000). This method has been successfully used in the nursery culture of oysters, scallops, clams, mussels and in numerous fish hatcheries (Andersen et al. 2000; Ritar 2001; Tieman and Goodwin 2001; Otoshi et al. 2003; Sarkis et al. 2006; Rico-Villa et al. 2008). Recirculating systems operate by water undergoing treatment, allowing to the hatcheries production system's waters to be partially reused (Rosenthal et al. 1986). This technology has been widely used in fish culture for more than three decades (Rosenthal 1980; Verreth and Eding 1993; Martins et al. 2005), but only recently has it been experimentally tested in nursery culture of some mollusk species such as Mercenaria mercenaria (Pfeiffer and Rusch 2000), Argopecten purpuratus (Merino et al. 2009) and Pecten maximus (Magnesen and Jacobsen 2012).

The aim of this paper is to enhance our understanding about the eventual effect of larvae rearing techniques and antimicrobial treatments at the breeder stage on the bacterial load in the rearing system to fulfill the goal of eliminating the antibacterial use at the larval stage. In this study, we investigate the impacts of the CAS and FTS on the growth, survival and microbiota associated with $R$. decussatus larvae.

\section{Materials and methods}

\section{Location of sampling area}

The study was carried out at the experimental bivalve hatchery of the National Institute of Marine Sciences and Technology (INSTM), Monastir, Tunisia, which is located on the 
edge of Monastir lagoon called Lake of Khniss. This lagoon communicates with the sea by a canal, of which a large part is artificial.

\section{Hatchery design and operation}

\section{Water treatment}

The water that feeds the experimental hall of bivalve mollusks and fish is a mixture between water lagoon and seawater at the proportion of 30 and $70 \%$, respectively. This water undergoes a sequential treatment: first sand filtration followed by a series of filtration pockets 25,5 and $1 \mu \mathrm{m}$. UV treatment was used for algae culture up to $5 \mathrm{~L}$ and for larvae culture up to the metamorphosis.

\section{Broodstock conditioning}

$R$. decussatus broodstock from the south of Tunisia (Gabes gulf) was conditioned according to Medhioub et al. (2006) protocol. The reproducers were treated with florfenicol (FF) at the dose of $8 \mathrm{mg} \mathrm{L}^{-1}$ day $^{-1}$ during 5 days before the spawning in order to create a barrier which limits the contamination of eggs and larvae. This treatment was incorporated with the food.

\section{Spawning, fertilization and incubation}

The spawning was realized according to Medhioub et al. (2006) protocol. Egg suspensions from the different adults are kept separate and should be filtered through $100-\mu \mathrm{m}$ nylon mesh prior to the addition of the recent dense sperm at the ratio $1-2 \mathrm{~mL} \mathrm{~L}^{-1}$ of egg suspension. Fertilization was achieved at $22-24{ }^{\circ} \mathrm{C}$. All fertilized eggs were pooled after $2 \mathrm{~h}$.

The embryos were transferred to a rectangular flat bottom plastic tank $(50 \mathrm{~L})$ at the density of $20 \times 10^{3}-40 \times 10^{3} \mathrm{~L}^{-1}$ and at $22-24{ }^{\circ} \mathrm{C}$. After $24-30 \mathrm{~h}$, most larvae reached D-shaped stage; the culture water was well exchanged and sifted through a $30-\mu \mathrm{m}$ nylon mesh. The D larvae were then counted before being transferred to a culture tank.

\section{Larvae culture method}

Two methods with different system of water circulation as described by Helm and Bourne (2004) were used for larvae up to the early pediveliger stage: traditional method with closed aquaculture system (CAS) and flow-through system (FTS). Both technics were carried in 210-L cylindroconic fiberglass tank filled with seawater at $20-21{ }^{\circ} \mathrm{C}$ and a mean salinity of 38 .

The experiment was conducted in a series of five tanks with three replicates, respectively: six tanks with FTS, three of which contained larvae produced by untreated breeders and the other three contained larvae obtained from florfenicol $\left(8 \mathrm{mg} \mathrm{L}^{-1}\right.$ day $^{-1}$ per 5 days)-treated breeders. Nine tanks with CAS, three of which received florfenicol treatment at $8 \mathrm{mg} \mathrm{L}^{-1}$ day $^{-1}$ during 3 days and the other six did not received treatment. In the closed aquaculture system, larvae were reared at a density of 5 larvae $\mathrm{mL}^{-1}$, and culture water was $100 \%$ renewed every 2 days where larvae received full food ration. Food ration will be at the half when the water is not renewed the following day. In flow-through 
system, 25 larvae $\mathrm{mL}^{-1}$ was used with water renewal equivalent at 6-7 time day ${ }^{-1}$ with continuous and constant distribution of feeding. Survival was scored at the end of the cylindroconical experiments.

When larvae reach the early pediveliger stage, they must be transferred from the both system to settling in tube cylinder of (sieves tube) 601 capacity with a circulating seawater system through $90-\mu \mathrm{m}$ nylon mesh where water renewal was equivalent to $0.14 \mathrm{~m}^{3} \mathrm{~h}^{-1}$.

\section{Feeding}

In this study, four species of microalgae were used: Chaetoceros sp, Isochrysis sp, Tetraselmis sp and Chaetoceros calcitrans. The first three strains were isolated from Tunisian coast, respectively, in 1998, 2002 and 2008 at INSTM Monastir Center.

In CAS and FTS, larvae were fed a mixture of Chaetoceros sp and Isochysis sp at the ration of 40 cells $\mu \mathrm{L}^{-1}$ as an initial ration during 3-4 days and 80 cells $\mu \mathrm{L}^{-1}$ as maximum ration up to the end of metamorphosis. This ration was equivalent to $40-80$ cells of Isochrysis and calculated on a cell volume equivalency basis where 1.0 cell of Isochrysis $\mathrm{sp}=2.08$ cells Chaetoceros $\mathrm{sp}$.

From early pediveliger stage to metamorphosis, three species of microalgae were used Isochrysis $\mathrm{sp}$, Cheatoceros calcitrans and Tetraselmis sp. The ration 80 cells of Isochrysis $\mu \mathrm{L}^{-1}$ was calculated in a cell volume equivalency basis where 1.0 cell of Isochrysis $\mathrm{sp}=0.87$ Chaetoceros calcitrans, 1.0 cell of Isochrysis $\mathrm{sp}=0.23$ Tetraselmis $\mathrm{sp}$.

\section{Measurement of larval length}

Sixty $R$. decussatus larvae were picked every 2 days from each culture, fixed in formolsaline for $30 \mathrm{~min}$ and conserved at $4{ }^{\circ} \mathrm{C}$. Larval specimens were photographed using a microscope (Zeiss, Germany) equipped with a digital camera. The anteroposterior length $(\mu \mathrm{m})$ was measured using Image $\mathbf{J}$ software 1.45 .

\section{Collection of samples}

Breeders, fertilized eggs and larvae were collected during all three ponds. Samples were immediately packed in UV sterilized oxygen-filled polythene bags separately, placed in an insulated container, and transported to the laboratory for analysis within $2 \mathrm{~h}$.

\section{Bacteriology}

\section{Bacterial count}

In this study, we used Marine agar (Ma) medium, for the enumeration of the moderately halophiles heterotrophic bacterial count, and thiosulfate citrate bile sucrose agar (TCBS modified agar; Scharlau Microbiogy, Spain) supplemented with $2 \% \mathrm{NaCl}$, specific for the Vibrionaceae biota. The enumeration of bacteria was carried out by using serial dilutions and the plating method to establish viable bacterial cell counts.

The water samples were tenfold serially diluted with artificial sterile seawater (ASSW), $1 \mathrm{~mL}$ aliquot of each dilution sample was spread out over the two media in duplicate. Colonies were counted after 24-48 $\mathrm{h}$ for the TCBS medium and 24-72 $\mathrm{h}$ for the marine 
agar medium, with incubation at $23{ }^{\circ} \mathrm{C}$. The results were expressed in colony forming units CFU mL ${ }^{-1}$ of water.

The breeder samples were washed thoroughly under running water, sprinkled with $70 \%$ ethanol and allowed to dry. Subsequently, the clams were opened aseptically using a sterile scalpel. Five grams of the intervalvar liquid and soft meat were homogenized with $5 \mathrm{~mL}$ of ASSW, and then, $1 \mathrm{~g}$ of the mixture was diluted with $4 \mathrm{~mL}$ of ASSW to obtain $10^{-1}$ diluted homogenate. Samples were tenfold serially diluted with artificial sterile seawater (ASSW), $1 \mathrm{~mL}$ aliquot of each dilution sample was spread out over the two media in duplicate. Colonies were counted after 24-48 $\mathrm{h}$ for the TCBS medium and 24-72 $\mathrm{h}$ for the marine agar medium, with incubation at $23{ }^{\circ} \mathrm{C}$. The results were expressed in CFU $\mathrm{g}^{-1}$ of clam-wet weight.

The fertilized eggs and larvae were enumerated by cell count under an optical microscope and were crushed in $1 \mathrm{~mL}$ of ASSW using an Eppendorf tube sterile pestle. The homogenate samples were serially diluted in the same solution, plated and counted as for the water samples. The count was multiplied by the dilution factor, divided by the number of the larvae and multiplied by $10^{5}$. The results were expressed in CFU $\times 10^{-5}$ eggs or larvae.

\section{Bacterial characterization}

Three suspected colonies from typical Vibrio colonies on TCBS medium were picked up, purified on TSA agar $(+2 \% \mathrm{NaCl})$ and then identified through different physiological and biochemical tests such as Gram nonstaining $(\mathrm{KOH})$ method, cytochrome oxidase activity, motility (Mannitol-Motility agar; Pronadisa, Madrid, Spain), resistance to vibriostatic O129 (10 and $150 \mu \mathrm{g}$ ), salt requirement (growth on $0,2,4,8$ and $10 \% \mathrm{NaCl}$ medium) and growth at 23 and $37{ }^{\circ} \mathrm{C}$. The species identification of Vibrio was performed using API $20 \mathrm{E}$ strips (bioMerieux, Marcy l'Etoile, France). The strains were conserved as frozen stocks at $-80{ }^{\circ} \mathrm{C}$ in tryptic soy broth (TSB; Bio-Rad, France) with $2 \% \mathrm{NaCl}$ plus $15 \%$ (v/v) glycerol.

\section{Statistical analysis}

All data were analyzed with SPSS version 21.0 software. Significance differences between bacterial counts were determined by the nonparametric Kruskal-Wallis test and MannWhitney test. Tukey test was used to obtain comparison between the larval growth means. Significance levels for all analysis were set at $P<0.05$.

\section{Results}

\section{Control of the bacterial biota}

The bacteriological control of $R$. decussatus reproducer showed in all three ponds treated with FF, a significant decrease $(P<0.05)$ in total viable counts (TVC) in Ma medium (Pond1, $T_{0}: 1.80 \times 10^{9}-T_{96}: 3.00 \times 10^{5} \mathrm{CFU} \mathrm{g}^{-1}$ ) as well as in presumptive Vibrio counts (PVC) in TCBS medium (Pond1, $T_{0}: 6.10 \times 10^{6}-T_{96}: 5.00 \times 10^{2} \mathrm{CFU} \mathrm{g}^{-1}$ ). However, these bacterial counts increased progressively in untreated ponds, respectively, by a factor of 2.00 and 3.50 in Pond 1. In addition, the fertilized eggs obtained from treated 
reproducers were free from any Vibrio contamination compared with those produced by untreated breeders (Table 1).

\section{Influence of rearing techniques on larval microbiota}

The assessments of the effects of rearing techniques on the bacterial load of $R$. decussatus larvae are presented in Tables 2 and 3, respectively. The total bacterial count for larvae reared in CAS without antimicrobial treatment ranged from $10^{4}$ to $10^{8} \mathrm{CFU} \times 10^{-5}$ larvae was significantly higher $(P<0.05)$ on the fourth day $\left(\mathrm{CAS}_{\mathrm{D} 4}: 10^{7}-10^{8} \mathrm{CFU} \times 10^{-5}\right.$ larvae) than in larvae maintained in other rearing systems (D4: $10^{3}-10^{6} \mathrm{CFU} \times 10^{-5}$ larvae). Moreover, a total larval mortality has occurred by the sixth day (Pond 1 and 3 ) and the eighth day (Pond 2) of rearing in closed system. The bacterial biota of larvae obtained after microbiological breeder barrier and reared in closed-circuit seawater system $\left(\mathrm{B}+\mathrm{CAS}_{\mathrm{D} 6}: 10^{6}-10^{8} \mathrm{CFU} \times 10^{-5}\right.$ larvae $)$ was significantly higher $(P<0.05)$ than in larvae reared in CAS and treated three times with $\mathrm{FF}$ at $8 \mathrm{mg} \mathrm{L}^{-1}\left(\mathrm{~B}+\mathrm{CAS}+\mathrm{FF}_{\mathrm{D} 6}: 10^{3}\right.$ $\mathrm{CFU} \times 10^{-5}$ larvae) .

The presumptive Vibrio spp. count for larvae obtained from FF-treated breeders and reared in FTS $\left(\mathrm{B}+\mathrm{FTS}_{\mathrm{D} 12}: 10^{2}-10^{3} \mathrm{CFU} \times 10^{-5}\right.$ larvae) was significantly lower $(P>0.05)$ than in FF-treated R.decussatus larvae and maintained in CAS $\left(\mathrm{B}+\mathrm{CAS}+\mathrm{FF}_{\mathrm{D} 12}: 10^{5} \mathrm{CFU} \times 10^{-5}\right.$ larvae $)$. On the eighth day of rearing, a total mortality was recorded in larvae produced in closed-circuit water system. In addition, larvae obtained from treated reproducers and reared in FTS $\left(\mathrm{BB}+\mathrm{FTS}_{\mathrm{D} 12}: 10^{2}-10^{3}\right.$ $\mathrm{CFU} \times 10^{-5}$ larvae $)$ showed significantly lower $(P>0.05)$ PVC than in larvae maintained in FTS $\left(\mathrm{FTS}_{\mathrm{D} 12}: 10^{4}-10^{5} \mathrm{CFU} \times 10^{-5}\right.$ larvae$)$.

\section{Influence of rearing techniques on larval growth and survival}

The results showed that larval length was significantly affected by the rearing techniques (Table 4). In fact, larvae grew successfully and completed their metamorphosis with $100 \%$ survival (data not presented) only when they were reared in B + FTS and $\mathrm{B}+\mathrm{CAS}+\mathrm{FF}$. $R$. decussatus larvae maintained in FTS showed significantly better length (Pond 2, B + FTS $_{\mathrm{D} 10}: 181.10 \mu \mathrm{m}$ ) than those produced in closed-circuit seawater system (Pond 2, B $+\mathrm{CAS}_{\mathrm{D} 10}: 145.10 \mu \mathrm{m}$ ). Moreover, Larvae produced by untreated breeders and reared in FTS showed significantly lower length (Pond 3, FTS D12: $_{\text {: }}$ : $168.40 \mu \mathrm{m}$ ) than those obtained from FF-treated reproducers (Pond 3, B + FTS $_{\mathrm{D} 12}$ : $201.90 \mu \mathrm{m})$. Growth of larvae maintained in B + FTS did not differ from growth of larvae reared in CAS and treated with FF (Table 4). Besides, survival was better in larval group reared in $\mathrm{B}+\mathrm{CAS}+\mathrm{FF}$ (up to $69 \%$ ) compared to those maintained in other rearing systems $(0-63 \%)$.

\section{Bacterial characterization}

A total of 112 strains were isolated from breeders $(n=42)$ and larvae $(n=70)$ collected from the INSTM clam hatchery and biochemically identified as members of the family Vibrionaceae by API 20 E miniaturized system (Table 5). Vibrio alginolyticus was the most predominant species (41/112) followed by V. fluvialis (28/112), V. vunificus (20/112), $V$. cholera (15/112) and $V$. paraheamolyticus (8/112). High phenotypic heterogeneity was observed among the tested isolates. In fact, the majority of Vibrio strains were positive for 


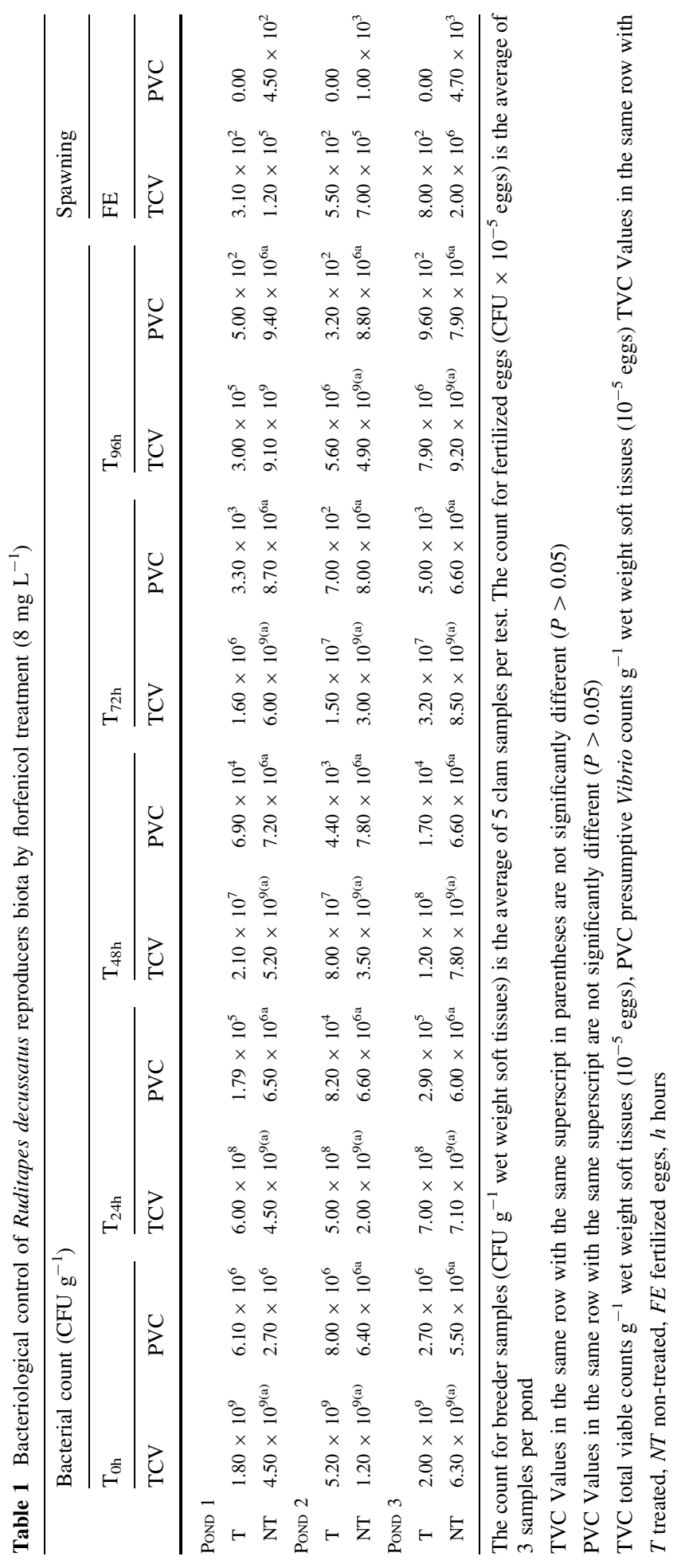




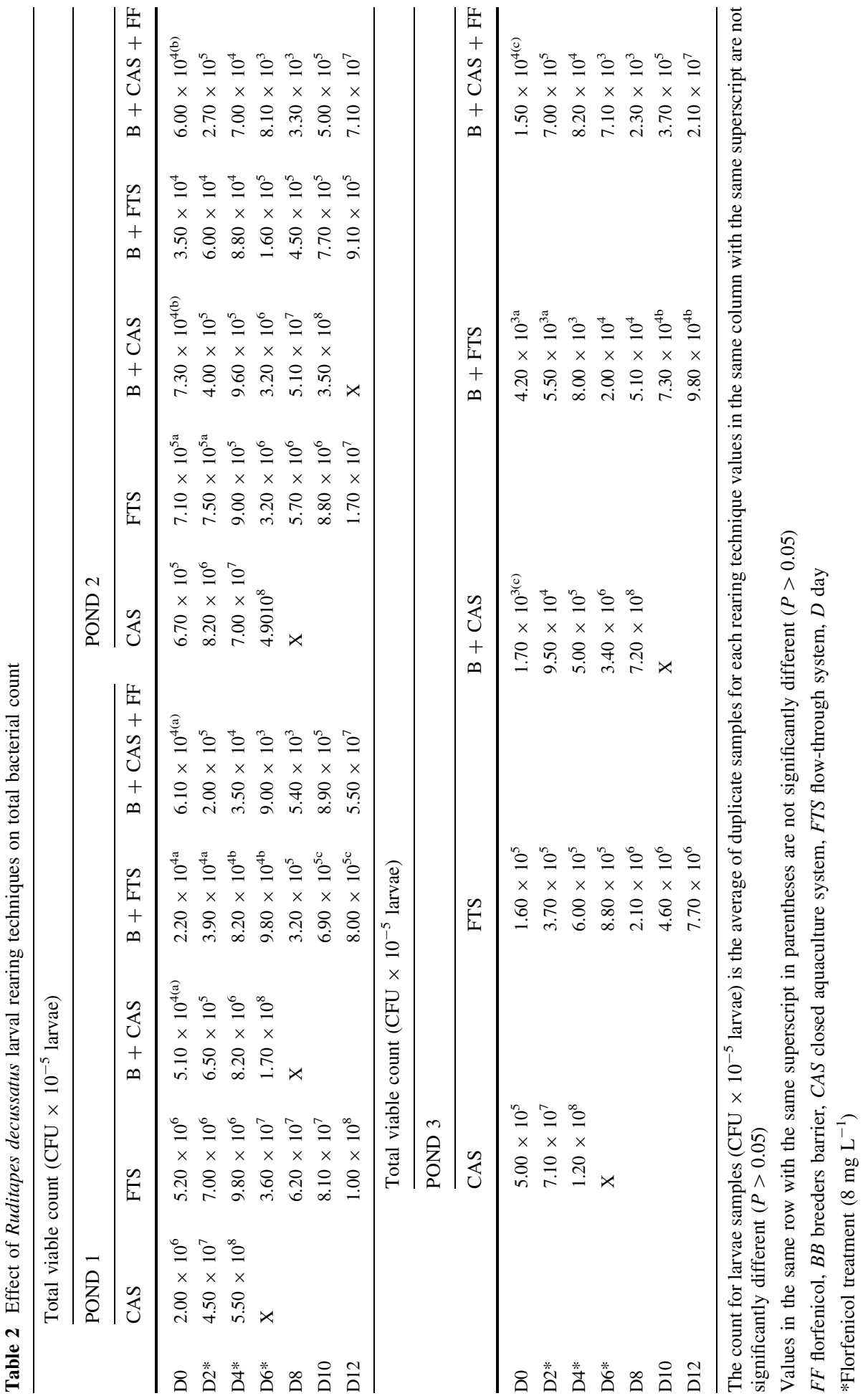




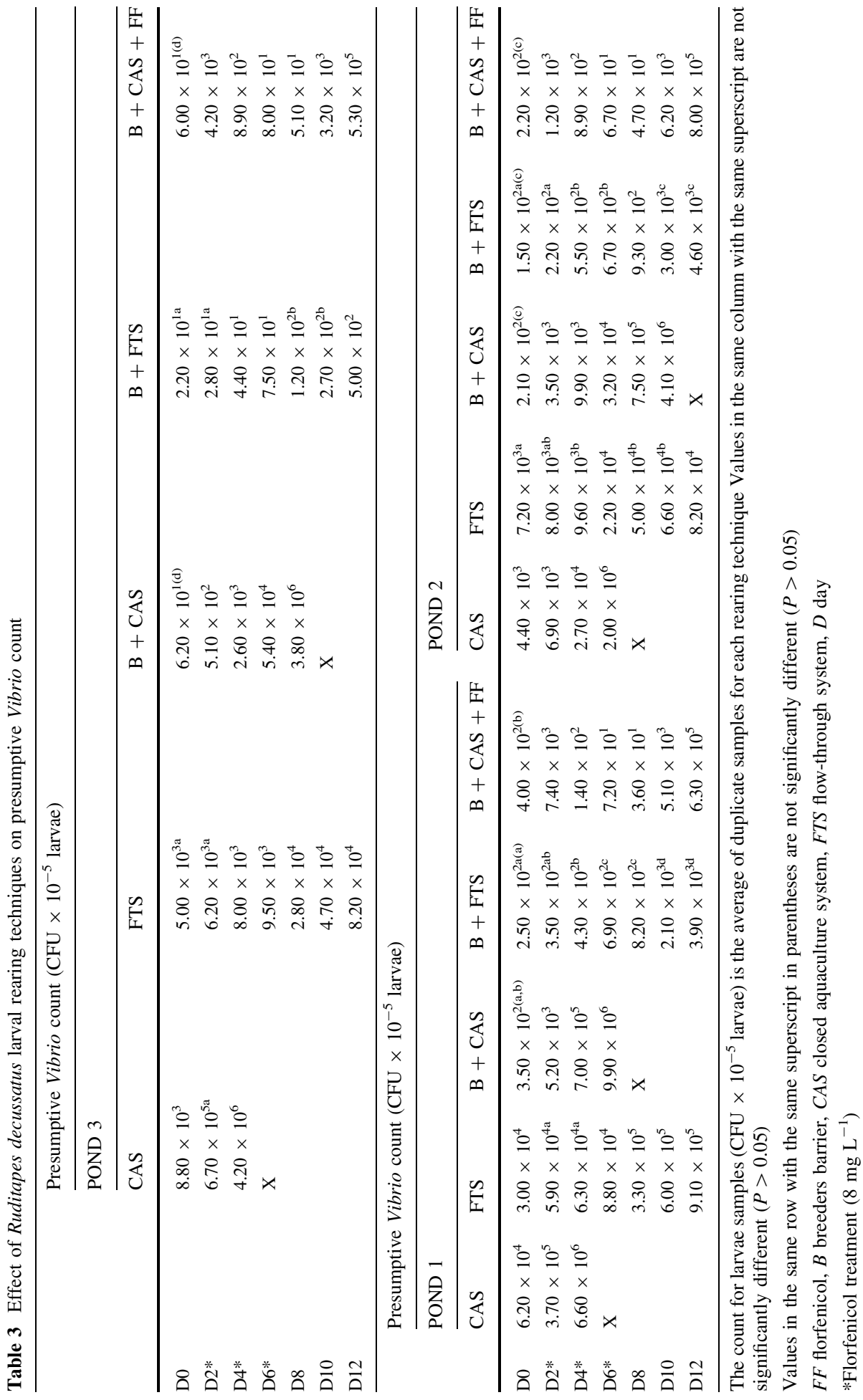




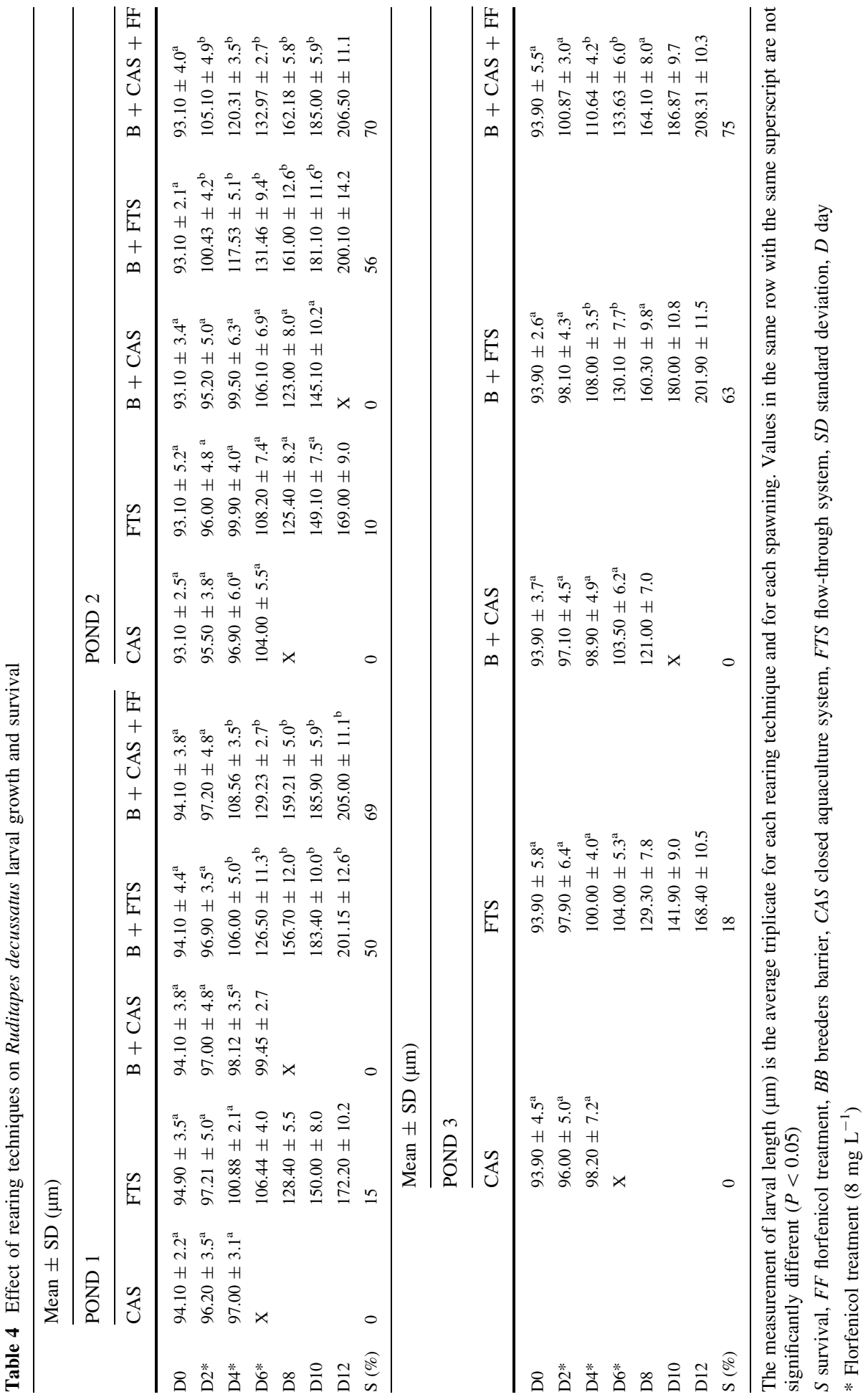


lysine decarboxylase, indole production and glucose fermentation. Only, V. fluvialis isolates gave positive results with adenine dehydrolase and tryptophan deaminase tests. About $75 \%(6 / 8)$ of the $V$. paraheamolyticus strains gave positive results with amygdalin and arabinose. Vibrio strains were able to tolerate low and moderate concentrations of $\mathrm{NaCl}$ (2-8\%), while only $V$. alginolyticus isolates were able to grow over a wide range of salinities $(0-10 \% \mathrm{NaCl})$.

\section{Discussion}

Members of the genus Vibrio are commonly found as part of the normal flora of molluscan intestinal tract (Oxley et al. 2002; Davis et al. 2013), thus making broodstock one of the principal sources of contamination in marine bivalve hatcheries. Several studies have been carried out on the gonads of reared mollusks revealed that they may be strongly infested with Vibrio (Lodeiros et al. 1987; Llanos et al. 2002; Sainz-Hernández et al. 2005) which leads to the hypothesis of their vertical transmission between reproducers and gametes. Widman (2001) suggested that Vibrio contamination into bivalve molluscan hatcheries can be controlled by relaying pre-spawning breeders for $24 \mathrm{~h}$ at $17-20{ }^{\circ} \mathrm{C}$ in filtered seawater. Conversely, Sainz-Hernández et al. (2005) revealed that this technique would not be sufficient for avoiding the circulation of vibrios into the clam system, since they found Vibrio in the gonadal tissue far from the digestive tract. In this study, we managed to create a bacteriological barrier among the breeder stage by FF treatments $\left(8 \mathrm{mg} \mathrm{L}^{-1}\right)$ for five successive days before spawning in order to reduce Vibrio dissemination and to eliminate the use of the antimicrobial agents for $R$. decussatus larval rearing. TCBS data showed a significant decreasing of PVC in broodstock after antibiotic treatments. Moreover, fertilized eggs originated from treated reproducers presented relatively better microbiological quality than those obtained from control breeders.

This study clearly demonstrated that $R$. decussatus larvae obtained from FF-treated breeders and reared in FTS showed significantly lower bacterial load, especially for vibrio count, than other techniques. These findings are in agreement with Andersen et al. (2000) who showed that great scallop larvae rearing water in flow-through tanks had fewer bacterial counts than both rearing water in antibiotic-treated and untreated static tanks. In addition, only larvae maintained in both CAS + FF and B + FTS succeeded to develop beyond the stage of metamorphosis. In the literature, it is reported that antibiotic treatments during larval rearing prevent bacterial contamination, which increases successful larval rearing (Robert et al. 1996; Uriarte et al. 2001; Torkildsen et al. 2005). However, the overuse of antibiotics in treatment of mollusk aquaculture may contribute to an increase in the level of antimicrobial resistance (Mechri et al. 2013, 2015). The introduction of a flowthrough system instead of closed-circuit water system in larval rearing tanks eliminated the use of antibiotics by improving water quality (Southgate and Ito 1998; Magnesen et al. 2006).

It was also noted that growth of larvae reared in B + CAS + FF and B + FTS was significantly better than those maintained in the other rearing systems. Phenicol are common broad-spectrum antibiotics used for aquacultural practice, as chemotherapeutic agents to manage and prevent diseases (Uriarte et al. 2001; Campa-Cordova et al. 2006; Mechri et al. 2012). Some countries have restricted the use of chloramphenicol and thiamphenicol in aquaculture because of their highly toxic potential on consumers (Van de Riet et al. 2003; Sarmah et al. 2006). FF is a fluorinated derivative of thiamphenicol with 
an expanded spectrum of activity and enhanced potency but with less harmful effects (Samuelsen and Bergh 2004; Xu et al. 2005). Thus, FF is often used to control bacterial disease outbreaks in mollusk larval hatcheries (Torkildsen et al. 2002; Torkildsen and Magnesen 2004; Miranda et al. 2013). However, several reports have demonstrated that the extensive use of antibiotics in aquaculture could facilitate the emergence and the selection of resistant bacteria (Laganà et al. 2011; Mechri et al. 2015). Previous studies of antimicrobial resistance in fish pathogenic bacteria have reported the occurrence of the floR gene as the major facilitator superfamily and code for efflux proteins that export florfenicol out of the cell (Miranda et al. 2013; Schwarz et al. 2004). Recently, Miranda et al. (2015) found that most of gram-negative bacteria associated with scallop hatcheries carried the floR gene.

Sarkis et al. (2006) showed that calico scallop growth for FT-reared larvae was comparable or significantly higher than in the static system, which corroborate with our findings. Similarly, Rico-Villa et al. (2008) reported significant growth and competence improvements in Crassostria gigas larvae reared in the flow-through system compared to static system. These authors also revealed that the use of FTS with constant flows of highquality water and a daily cleaning of the sieve clogs facilitated the circulation in the rearing tank and removal of metabolic waste products providing favorable conditions for larval development. Several studies suggested an association between the stocking density and the water exchange rate (Magnesen et al. 2006; Rico-Villa et al. 2008). Furthermore, Andersen et al. (2000) and Sarkis et al. (2006) reported a reduction in growth performance at high stocking density when they reared scallop (Pecten maximus) and oyster (C. gigas) larvae in FTS.

Survival of $R$. decussatus larvae reared in $\mathrm{B}+\mathrm{CAS}+\mathrm{FF}$ was better than for those maintained in other rearing techniques. These findings are in agreement with Andersen et al. (2000) who showed that in spite of low bacterial counts in great scallop larvae, increased larval survival was not demonstrated in the FTS compared to the antibiotictreated CAS. Torkildsen and Magnesen (2004) reported that P. maximus larval survival in FTS was approximately similar to survival in CAS with prophylactic addition of chloramphenicol. Besides, Temperature and algal concentration were the most important factors that affect growth and survival (Le Pennec et al. 2003; Pernet and Tremblay 2004).

The predominant species isolated from almost all of broodstock and larvae samples was $V$. alginolyticus $(36.6 \%$ ). This species has become increasingly recognized as an important opportunistic pathogen causing epizootic outbreaks in cultured fish (Ben Kahla-Nakbi et al. 2006), shellfish (Beaz Hidalgo et al. 2008) and crustaceans (Gomez-Gil et al. 1998). In our previous study, we found that $V$. alginolyticus species was the most commonly isolated (55\%) from the different compartments of $R$. decussatus hatchery (Mechri et al. 2012). Castro et al. (2002) characterized 123 Vibrio isolates from cultured Ruditapes philippinarum using phenotypic and genotypic methods and showed that $V$. harveyi, $V$. splendidus and V. tubiashii were the most abundant species. Moreover, Beaz Hidalgo et al. (2008) reported that $67.7 \%$ of the Vibrio species associated with cultured carpet shell clams (R. decussatus) and Manilla clams (R. philippinarum) belonged to V. splendidus, $V$. alginolyticus and $V$. diazotrophicus.

Phenotypic characteristics of Vibrio isolates recovered from INSTM hatchery revealed high levels of identity. In fact, 112 Vibrio strains isolated on TCBS agar were further biochemically identified using the commercial miniaturized Api 20E kit and showed biochemical profiles similar to those reported earlier by Mechri et al. (2012). Conversely, these finding disagree those of Al-Sunaiher et al. (2010) who showed that the majority of $V$. fluvialis strains, isolated during fish outbreak, were positive to indole test and were able 
to ferment mannitol. These authors also reported that all $V$. vulnificus strains gave negative result with lysine decarboxylase and were unable to ferment glucose and amygdalin.

\section{Conclusion}

In this paper, we demonstrate that the prophylactic use of FF at breeder stage improve the bacteriological quality of $R$. decussatus eggs. Despite considerable variability of the Vibrio load, no significant differences in growth performance were noted among larvae reared in B + FTS and B + CAS + FF. Thus, FTS appears to be an alternative that can eliminate the need for antibiotic treatments during larval rearing. However, several important parameters, such as larval densities, temperature and alimentation, need optimization to improve $R$. decussatus rearing performance. We also reported that $V$. alginolyticus strains were predominantly isolated from breeders, eggs and larvae. Further research is needed to understand the boundaries between commensalism and pathogenicity in this species.

Open Access This article is distributed under the terms of the Creative Commons Attribution 4.0 International License (http://creativecommons.org/licenses/by/4.0/), which permits unrestricted use, distribution, and reproduction in any medium, provided you give appropriate credit to the original author(s) and the source, provide a link to the Creative Commons license, and indicate if changes were made.

\section{References}

Al-Sunaiher AE, Abdelnasser S, Ibrahim S, Al-Salamah A (2010) Association of Vibrio species with disease incidence in some cultured fishes in the Kingdom of Saudi Arabia. World Appl Sci J 8(5):653-660

Andersen S, Burnell GG, Bergh OO (2000) Flow-through systems for culturing great scallop larvae. Aquacult Int 8:249-257

Beaz Hidalgo R, Cleenwerck I, Balboa S, De Wachter M, Thompson FL, Swings J, De Vos P, Romalde JL (2008) Diversity of Vibrios associated with reared clams in Galicia (NW Spain). Syst Appl Microbiol 31:215-222

Ben Kahla-Nakbi A, Chaieb K, Besbes A, Zmanter T, Bakhrouf A (2006) Virulence and enterobacterial repetitive intergenic consensus PCR of Vibrio alginolyticus strains isolated from Tunisian cultured gilthead sea bream and sea bass outbreaks. Vet Microbiol 117:321-327

Campa-Cordova AI, Luna-Gonzalez A, Ascencio F, Cortes-Jacinto E, Caceres- Martınez CJ (2006) Effects of chloramphenicol, erythromycin, and furazolidone on growth of Isochrysis galbana and Chaetoceros gracilis. Aquaculture 260:145-150

Castagna M, Gibbons MMC, Kurkowski KK (1996) Culture: application. In: Kennedy VS, Newell RIE, Eble AF (eds) The eastern oyster, Crassostreaa virginica. Maryland Sea Grant, College Park, pp 675-690

Castro D, Pujalte MJ, Lopez-Cortes L, Garay E, Borrego JJ (2002) Vibrios isolated from the cultured Manila clam (Ruditapes philippinarum): numerical taxonomy and antibacterial activities. J Appl Microbiol 93:438-447

Davis J, Fricke WF, Hamann MT, Esquenazi E, Dorrestein PC, Hill RT (2013) Characterization of the bacterial community of the chemically defended Hawaiian sacoglossan Elysia rufescens. Appl Environ Microbiol 79:7073-7081

Gomez-Gil B, Tron-Mayén L, Roque A, Turnbull JF, Inglis V, Guerra-Flores AL (1998) Species of Vibrio isolated from hepatopancreas, haemolymph and digestive tract of a population of healthy juvenile Penaeus vannamei. Aquaculture 163:1-9

Helm MM, Bourne N (2004) Hatchery culture of bivalves. A practical manual. In: Lovatelli A (ed) FAO Fisheries Technical Paper 471. Food and Agriculture Organization of the United Nations Publishing, Rome, p 177

Laganà P, Caruso G, Minutoli E, Zaccone R, Santi D (2011) Susceptibility to antibiotics of Vibrio spp. and Photobacterium damsela ssp. piscicida strains isolated from Italian aquaculture farms. New Microbiol 34(1):53-63 
Le Pennec M, Paugam A, Le Pennec G (2003) The pelagic life of pectinid Pecten maximus-a review. ICES J Mar Sci 60:211-223

Llanos J, Cid M, Navarro S, Dinamarca A, García-Tello P (2002) Atypical bacteria accompanying the scallop Argopecten purpuratus. Invest Mar Valparaíso 30(2):57-59

Lodeiros C, Bolinches J, Dopazo CP, Toranzo AE (1987) Bacillary necrosis in hatcheries of Ostrea edulis in Spain. Aquaculture 65:15-29

Magnesen T, Jacobsen A (2012) Effect of water recirculation on seawater quality and production of scallop (Pecten maximus) larvaee. Aquacult Eng 47:1-6

Magnesen T, Bergh O, Christophersen G (2006) Yields of great scallop, Pecten maximus, larvaee in a commercial flow through rearing system in Norway. Aquacult Int 14:377-394

Martins CIM, Eding EH, Schneider O, Rasmussen R, Olesen B, Plesner L, Verreth JAJ (2005) Recirculation aquaculture systems in Europe. CONSENSUS. Oostende, Belgium, Consensus working Group, European Aquaculture Society: 31

Mechri B, Medhioub A, Medhioub MN, Aouni M (2012) Diversity of Vibrionaceae associated with Ruditapes decussatus hatchery in Tunisia. Ann Microbiol 61:597-606

Mechri B, Medhioub A, Medhioub MN, Aouni M (2013) Genotypic diversity, antimicrobial resistance and screening of Vibrio cholerae molecular virulence markers in Vibrio alginolyticus strains recovered from a Tunisian Ruditapes decussatus hatchery. Pol J Microbiol 62(3):263-272

Mechri B, Ben Salem I, Medhioub A, Medhioub MN, Aouni M (2015) Isolation and genotyping of potentially pathogenic Vibrio alginolyticus associated with Ruditapes decussatus larvae and juvenile mass mortalities. Aquacult Int 23(4):1033-1047

Medhioub MN (1983) La conchyliculture en Tunisie. Projet Tunis/92/002. Direction Générale de la Pêche et de l'Aquaculture. PNUD/FAO. pp 83

Medhioub MN, Lymayem Y, Fathallah S, Abed MM, Medhioub A (2006) Cycle d'élevage de la palourde Ruditapes decussatus (mollusque lamellibranche) produite en écloserie. Actes des 13ème Journées Scientifiques sur les Résultats de la Recherche Agricoles, pp 107-117

Merino G, Uribe E, Soria G, von Brand E (2009) A comparison of larval production of the northern scallop, Argopecten purpuratus, in closed and recirculating culture systems. Aquacult Eng 40:95-103

Miranda CD, Tello A, Keen PL (2013) Mechanisms of antimicrobial resistance in finfish aquaculture environments. Front Microbiol 4:233

Miranda CD, Rojas R, Geisse J, Romero J, González-Rochac G (2015) Scallop larvae hatcheries as source of bacteria carrying genes encoding for non-enzymatic phenicol resistance. Marine Poll Bull 95:173-182

New MB, Valenti WC (2000) Freshwater prawn culture: the farming of Macrobrachium rosenbergii. Blackwell Science, Oxford, p 52

Otoshi CA, Arce SSM, Moss SSM (2003) Growth and reproductive performance offbroodstock shrimp reared in a biosecure recirculating aquaculture system versus a flow-through pond. Aquacult Eng 29:93-107

Oxley APA, Shipton W, Owens L, McKay D (2002) Bacterial flora from the gut of the wild and cultured banana prawn, Penaeus merguiensis. J Appl Microbiol 93:214-223

Pernet F, Tremblay R (2004) Effect of varying levels of dietary essential fatty acid during early ontogeny of the sea scallop Placopecten magellanicus. J Exp Mar Biol Ecol 310:73-86

Pfeiffer TJ, Rusch KA (2000) An integrated system for microalgal and nursery seed clam culture. Aquacult Eng 24:15-31

Rico-Villa B, Woerther PP, Mingant CC, Lepiver DD, Pouvreau SS, Hamon MM, Robert RR (2008) A flowthrough rearing system for ecophysiological studies of Pacific oyster Crassostrea gigas larvaee. Aquaculture 282:54-60

Rico-Villa B, Le Coz JR, Mingant C, Robert R (2006) Influence of phytoplankton diet mixtures on microalgae consumption, larval development and settlement of the Pacific oyster Crassostrea gigas (Thunberg). Aquaculture 256:377-388

Ritar AJ (2001) The experimental culture of phyllosoma larvaee of southern rock lobster (Jasus edwardsii) in a flow-through system. Aquacult Eng 24:149-156

Robert R, Gérard AA (1999) Bivalve hatchery technology: the current situation for the Pacific oyster Crassostrea gigasa and the scallop Pecten maximus in France. Aquat Living Resour 12:121-130

Robert R, Miner P, Nicolas JL (1996) Mortality control of scallop larvaee in the hatchery. Aquacult Inter 4(4):305-313

Rosenthal H (1980) Recirculation systems in Western Europe. World symposium on aquaculture in heated effluents and recirculation system, Stavanger, Institut für Kuesten-und Binnefischerei, Bundesforschungsanstalt Hamburg, BRD 
Rosenthal H, Castell JD, Chiba K, Forster JRM, Hilge V, Hogendoorn H,Mayo RD, Muir JF, Murray KR, Petit J, Wedemeyer GA, Wheaton F, Wickins J (1986) Flow-through and recirculation systems, EIFAC, p 100

Sainz-Hernández JC, Martínez M, Alfonso N (2005) Sources of Vibrio bacteria in mollusc hatcheries and control methods: a case study. Aquacult Res 36:1611-1618

Samuelsen OB, Bergh O (2004) Efficacy of orally administered florfenicol and oxolinic acid for the treatment of vibriosis in cod (Gadus morhua). Aquaculture 235:27-35

Sarkis S, Hohn CC, Helm MM (2006) Larval rearing of calico scallops, Argopecten gibbus, in a flowthrough system. Aquacult Int 14:527-538

Sarmah AK, Meyer MT, Boxall ABA (2006) A global perspective on the use, sales, exposure pathways, occurrence, fate and effects of veterinary antibiotics (VAs) in the environment. Chemosphere 65:725-759

Schwarz S, Kehrenberg C, Doublet B, Cloeckaert A (2004) Molecular basis of bacterial resistance to chloramphenicol and florfenicol. FEMS Microbiol Rev 28:519-542

Southgate PC, Ito MM (1998) Evaluation of a partial flow-through culture technique for pearl oyster (Pinctada margaritifera L.) larvaee. Aquacult Eng 18:1-7

Tieman DM, Goodwin AAE (2001) Treatments for ich infestations in channel catfish evaluated under static and flow-through water conditions. N Am J Aquacult 63:293-299

Torkildsen L, Magnesen T (2004) Hatchery production of scallop larvaee (Pecten maximus) survival in different rearing systems. Aquacult Int 12:489-507

Torkildsen L, Coyne R, Samuelsen OB, Magnesen T, Bergh $\varnothing$ (2002) Treatment of the early life stages of scallop (Pecten maximus) with antimicrobial agents; searching for an alternative to chloramphenicol. Aquacult Int 10(5):399-409

Torkildsen L, Lambert C, Nylund A, Magnesen T, Bergh Ø (2005) Bacteria associated with early life stages of the great scallop, Pecten maximus: impact on larval survival. Aquacult Int 13(6):575-592

Uriarte I, Farías A, Castilla JC (2001) Effect of antibiotic treatment during larval development of the Chilean scallop Argopecten purpuratus. Aquacult Eng 25(3):139-147

Van de Riet JM, Potter RA, Christie-Fougere M, Garth-Burns B (2003) Simultaneous determination of residues of chloramphenicol, thiamphenicol, florfenicol and florfenicol amine in farmed aquatic species by liquid chromatography/mass spectrometry. J AOAC Int 86:510-514

Verreth JAJ, Eding EH (1993) European farming industry of African catfish (Clarias gariepinus) facts and figures. J World Aquacult Soc 24:6-13

Widman JC (2001) Manual for hatchery culture of the bay scallop, Argopecten irradians irradians. National Marine Fisheries Service, Connecticut Sea Grant College Program, Connecticut, p 50

$\mathrm{Xu}$ LW, Liao CR, Liu GF (2005) Security about florfenicol used in aquaculture. J Fish Sci China 12:512-518 